\title{
A. Amenta, T. Kaliściak, B. Warkocki (red.), Dezorientacje. Antologia polskiej litera- tury queer, Wydawnictwo Krytyki Politycznej, Warszawa 2021, pp. 909.
}

The 2015 decision of the National Program for the Development of Humanities, an important Polish government agency, to fund an anthology of Polish queer literature was followed by consternation in the mainstream media. The national character of the Program and its focus on tradition and heritage clashed with queer studies, a field often envisioned as foreign, subversive, and set against national values. It was argued that queer and LGBT studies refer only to minorities, while state funds should be spent on universal projects, connected to the heritage of the whole nation. The agency director had to justify the decision, explaining that the aim of the project was to acknowledge the existence of Polish queer literature and to fill under-researched gaps in a larger vision of tradition. However, Disorientations do achieve more than this: by reinterpreting the Polish canon, they subvert its common, heteronormative understandings.

The anthology was published in 2021; on 900 pages it includes almost 300 texts by over 100 authors. Its vast scope legitimizes queer as a major part of Polish culture. Second, the volume confirms that queer literature should not be considered just a periphery referring to minorities, but must be placed also in the center of the canon. In Disorientations, the works written by the icons of Polish literature turn out queer. Because of its legitimizing, canonical character, this edition is audacious, but not radical, subversive, but not revolutionary.

The editors associate queer with non-heteronormativity. Thus, the anthology presents a variety of threads connected to untypical genders, sexualities, and desires. After Eve Kosofsky Sedgwick, it grasps their entanglement in homophobia and homosocial attraction, and it stresses both variability and centrality of masculinities. Such an approach, founded in the methodology formulated in the I990s, may seem rather narrow today, as it excludes from the range of queerness all untypical bodies whose oddness is not connected to sex or gender. On the other hand, this focus ensures coherence of the selection. Transgressions - a series of books by Maria Janion focusing on otherness and exclusion, especially the two first volumes published at the beginning of the 1980 os entitled Galley-slaves of Sensitivity and The Misfits provide the second theoretical approach important to the concept of the anthology. This tradition exposes femininity, which indeed finds a decent representation in Disorientations, including visions of the feminine homosocial continuum, lesbian threads, and diverse variants of non-normative gender. Furthermore, the editors continue the tradition of Transgressions when they include Jewishness into the orbit of queerness. Certainly, it is crucial for Polish practices of queering and exclusion. 
The volume focuses on literary texts. Poetry and novel excerpts prevail, but essays, letters, diaries, literary criticism and drama are also covered. The editorial apparatus deserves attention: an extensive introduction, biographical notes that expose queer experience, footnotes, contexts, as well as detailed bibliographical data respond to the needs of the non-professional reader. The footnotes that contextualize an excerpt in the whole work are indispensable especially in cases of longer texts, such as novels or dramas, shown only in passages that usually do not exceed 5 pages. Such an economic formula proves exceptionally useful in teaching. Also, thanks to its form, the anthology presents a panorama, a compendium, or a reader, a point of departure for following inquiries.

The volume consists of four chapters, divided by the turning points of Polish history: 1918, 1945, and 1989. The Old-Polish period is missing; the reason for this may be the previously published anthology, although based on different theoretical assumptions, entitled Old-Polish Homosexuality (20I4). As a result, Disorientations refer to modern literature, covering the period from the late Enlightenment till the $100^{\text {th }}$ anniversary of the Poland's independence, celebrated in 2018 . The volume starts with the poem To a Friend by Franciszek Karpiński, the author of a popular Christmas carol, who stereotypically would be linked to anything else but queerness. Every next chapter is more extensive, while the last one proves exceptional vividness of queer topics in the most recent Polish literature. It also emphasizes the activity of women writers, who seem to destabilize particularly enthusiastically (and effectively) the Polish patterns of gender and sexuality.

The compilation of short excerpts written by numerous authors encourages the reader to trace intertextual relations. The editors suggest links; they explain where to look for queerness and clarify references and allusions, which otherwise would require expert knowledge to decipher. Thanks to these glosses, non-professional readers can observe the long duration of queer imagery and the process of shaping certain queer tradition. At the same time, the edition displays radical changes and transformations in the way gender and sexuality are approached and therefore proposes to broaden the language to describe non-normative forms of intimacy. In consequence, it seems that the tenor of the anthology is accordant to the assumptions of LGBT identity politics.

Polish literature describes a whole range of queer practices: erotic fascination, desire, pleasure and fulfillment, melancholy and mourning, shame, cruising, activism, and coming out. At the same time, the authors' bios show that their life experiences were similar to the very conventional, normative visions of the fate of the Polish intellectual: emigrations, deportations, war traumas, clandestine political activism, and subsequent waves of emigrations. The tension between sexual and national identity still organizes the way gender and sexuality are perceived in Poland. This matter is also problematized in the texts in the anthology. Witold Gombrowicz in the novel Trans-Atlantic connects homosexuality with a project of "sonland" - a formula of modernity and masculinity opposed to the "fatherland" that revaluates the fossilized national tradition. Paweł Demirski in the drama Rainbow Tribune asks about the possibility of creating a sector for queer fans at the European Football Championship, while in Poland football stadiums are considered a space of nationalism, homophobia, and antisemitism. Joanna Bednarek in her avant-garde novel On the Origin of Family criticizes the conventional mental image of a sanctified, traditional, patriarchal Polish family, using a perspective of a daughter-Jewess. Thus, the anthology destabilizes existing identities and at the same time it refreshes the canon.

Most importantly, it queers the authors of the national literary pantheon. The most important figures in the first chapter are Polish romantics, among others Adam Mickiewicz and Juliusz Słowacki, great "national" poets, as well as Henryk Sienkiewicz, the Nobel-awarded novelist aiming in his writings to "uplift Polish hearts". Discussing Romanticism, the anthology features the 
model of masculinity and male homosocial relations, whose tenderness - as the editors notice in the introduction - seems surprising and suspicious today. These relationships are distinguished, on the one hand, by the asexual character of practices that today are linked to sexuality (sleeping together, kisses, embraces), on the other hand, by deep emotional engagement (exclusiveness and secrecy of feelings, jealousy, sadness after separation, readiness for sacrifice, etc.), often greater than in the heterosexual relations. The romantic authors turn out queer in the sense that they actualize a different organization of desire, an alternative intimacy: anti-hierarchical, anti-productive, founded in identity, not in difference. Therefore, the anthology shows that love beyond the dichotomic sex regime is obvious for some leading figures of the school literary canon.

In November 202I, the Polish Parliament dominated by the populist right announced 2022 the year of Polish Romanticism. The resolution perpetuates the stereotype that romantic literature shaped Polish national identity, underlying its conservative character. The Anthology of Polish Queer Literature complicates this oversimplified narration, showing that sentimentalism and romanticism marked the beginning of a new model of love that later has become an important element of homosexual identity. The polyphonic anthology explores numerous forms of sexuality, femininity, masculinity, and community that are not only contested by the today's Polish authorities, but even openly and persistently erased.

A protagonist of Michał Głowiński's autobiographical narrative Bar Ganymede fights against his prejudices, fears, and reluctances that restrain him from entering a gay bar in an anonymous western city in the 1980 s. He quotes ironically the words of Henryk Sienkiewicz's historical novel With Fire and Sword: "Bar... has been taken". Bar, today a town in Ukraine, was a Polish frontier fortress unsuccessfully defended against rebelled Cossacks. Gay bar's door turned out impassable for the Głowinski's protagonist; afraid of exposure, overwhelmed by personal complexes, and estranged by persons seen in the window, he did not decide to come in. Today a safe space of gay bars is accessible for better-off inhabitants of Polish metropolises. Still, if entering the bar means overcoming homophobic complexes, transgressing restrictive visions of Polish literature, and formulating alternative traditions, then the anthology helps to side with the queer Cossack rebels to finally step in. 